\title{
Countermeasures Research on Developed Countries Using Intellectual Property to Promote the Development of Strategic Emerging Industries
}

\author{
Jie Lin \\ School of Economics and Management, Changchun University of Science and Technology \\ 7989, Weixing Road, Changchun 130022, Jilin Province, China \\ Tel: 86-133-532-06711_E-mail: 39446854@qq.com \\ Yuzheng Han (Corresponding author) \\ Personnel Department, Changchun University of Science and Technology \\ 7089, Weixing Road, Changchun 130022, Jilin Province, China
}

Received: September 22, 2012

Accepted: October 15, 2012

Online Published: November 27, 2012

doi:10.5430/bmr.v1n4p117

URL: http://dx.doi.org/10.5430/bmr.v1n4p117

This paper is one of phased achievements of a project "Countermeasures Research on the Development of Strategic Emerging Industries in Changchun in the perspective of sustainable development" (2012ssk20) of Changchun Philosophy and Social Science Planning Program.

\begin{abstract}
The strategic emerging industry is the industry that emerges in one country or region along with the implementation of technical innovation achievements and has strategic effects on economic and social development. To develop the strategic emerging industries is a significant action to promote the upgrading of industrial structure and transform the pattern of economic growth, as well as a strategic option for following the new scientific and technological revolution and dealing with the international financial crisis. For Japan, the U.S., Germany, and other developed capitalist countries, the main experiences for the development of strategic emerging industries are: highly integrate the intellectual property strategy with the development strategy of strategic emerging industries, apply the dynamic management, and smoothly connect the new ideas of the strategic emerging industries with the new market. In China, in order to develop the strategic emerging industries, we should learn from the successful experiences of developed countries, draft the promotion strategy of intellectual property at the national and industrial levels, provide protections for the development of strategic emerging industries, and effectively promote the development of strategic emerging industries.
\end{abstract}

Keywords: Intellectual property, Strategic emerging industry, Countermeasures

The international financial crisis has brought a serious impact on the global industrial development. Countries are all trying to take various actions to deal with the crisis. Noticeably, during the international financial crisis, many countries have introduced relevant policies to foster the emerging industries. For example, the U.S. has developed the "Obama - Biden New Energy Plan", by which the Government plans to invest $\$ 150$ billion in the next 10 years and focuses on the development of hybrid cars, next-generation bio-fuels, clean coal technology, etc. trying to make the U.S. be the world leader of the new energy industry development. Europe decides to invest 105 billion Euros for the development of "green economy" before 2013, bringing new impetus for the economic growth. The UK develops the "manufacturing strategy" and plans to focus on the development of ultra-low carbon vehicles, life sciences and medicine, and cutting-edge manufacturing industry.

In October 10, 2010, the State Council promulgated the Decision of the State Council on Accelerating the Fostering and Development of Strategic Emerging Industries, in which the Government took the energy saving and environmental protection industry, the new-generation information technology industry, the bio-industry, the high-end equipment manufacturing industry, the new energy industry, the new material industry, and the new-energy automobile industry as the strategic emerging industries, and plans that the proportion of value-added of strategic emerging industries to the GDP respectively reaches about $8 \%$ in 2015 and 18\% in 2020. The Twelfth Five-Year Plan 
for National Economic and Social Development of the People's Republic China proposes to foster the strategic emerging industries and make them be the pilot and pillar industries. To develop the strategic emerging industries is an effective way for accelerating the upgrading of industrial structure and transforming the pattern of economic growth, which has an important significance for China improving the capability of independent development and international competitiveness, and promoting the sustainable economic and social development.

\section{The developed countries have successfully promoted the development of strategic emerging industries by intellectual property}

The strategic emerging industries refer to a series of industries, which are based on the fruits of intellectual property and have strategic meanings for economic development, mainly including the energy saving and environmental protection industry, the new-generation information technology industry, the bio-industry, the high-end equipment manufacturing industry, the new energy industry, the new material industry, and the new-energy automobile industry, etc. (General Office of the State Council of the People's Republic of China). They are the leading and new industries. They have the most advanced technologies in the world, with high-tech, high value-added, high growth, low consumption of resources, and low environmental pollution. The strategic emerging industries are the high ground, for which the countries compete in the new round of economic and scientific \& technological development. After the developed countries' long-term development and enhancement, the intellectual property has become the production factor for strategic emerging industries and the foundation for the creation of new competitive advantages. In Japan, the U.S., Germany, and other developed countries, using the intellectual property to promote the development of strategic emerging industries is very successful. Not only the development of strategic emerging industries play a significant role in boosting the country's economic growth, but also has extremely important effects on world economic development today. The strategic emerging industries are the new trend in the world economy.

\section{The features of developed countries promoting the development of strategic emerging industries by intellectual property}

With increasingly market competition, the developed countries use the intellectual property to promote the development of strategic emerging industries and take it as the primary strategy. The main features are reflected in the following aspects:

\subsection{The high integration of the intellectual property strategy with the development strategy of emerging industries}

The high integration of the intellectual property strategy with the development strategy of emerging industries is an inevitable trend to enhance the development performance of strategic emerging industries, and also the urgent need for developed countries achieving the development goals of strategic emerging industries. In Japan, the exploitation of patent for strategic emerging industries has achieved high performances. Its average exploitation rate of patent is $52 \%$, much higher than the world average. Early in November, 2000, Japan promulgated the "National Policy for Information Technology", which clearly mentioned that the Government would invest 10 trillion dollars to develop the information technology and other strategic emerging industries thoroughly (Gang Wan, 2010). Besides, the Government would take a series of strategic measures to promote the exploitation of patent for strategic emerging industries and use the intellectual property to improve the performances of strategic emerging industrial development. The German Government is committed to advancing the high integration of intellectual property strategy with the development strategy of emerging industries, which makes the quantity of patent applications be the highest in Europe, significantly promoting the industrial development. According to the statistics of the European Patent Office in 2009, Germany ranked the first with 25107 patent applications (18.7\%). The U.S. adopts a series of measures to promote the mastery and the application of intellectual property, achieving the healthy development of strategic emerging industries. For example, in the past two decades, the U.S. invested more than $\$ 160$ billion in the R\&D for advanced technologies annually. Besides, the Government established the direction of the development of strategic emerging industries, especially the information industry, took the intellectual property-intensive strategic industries, including the environmental protection, the computer, the communication, the consultation, the software, and the service as the 6 major export industries, and attached great importance to the high integration of the intellectual property strategy and the development strategy of emerging industries (Weina $\mathrm{Li}, 2009$ ).

2.2 The positive interaction mechanism for $R \& D$ and industrialization comes into being within the enterprise and between enterprises and research institutions

In order to stimulate more innovations in the development of strategic emerging industries, the developed countries generally introduce various incentive mechanisms and produce appropriate incentives according to the outcome of enterprise inventors. For example, the IBM Corporation in the United States accumulates scores for the inventors, 
three scores for the patent for an invention, and one score for the invention published in Technical Bulletin. The IBM will give the inventor a reward of $\$ 3600$ when the inventor wins 12 scores. Toshiba Corporation of Japan divides the inventions into five levels. The minimum bonus of one invention is 4000 yen and the maximum bonus in a year is up to 0.6-1 million yen. Some developed countries establish special R\&D institutions and scientific zones in order to introduce, consume, absorb, and improve the latest technologies and train high-level scientific research personnel (Gang Zhao, 2010). For instance, as early as in the early 1980s, the Japanese MITI (Ministry of International Trade and Industry) attracted amounts of emerging industries, universities, and R\&D institutions purposely and achieved the close association of "production, learning, and research". The JULIC Research Center, jointly established by the German federal government with $90 \%$ of the total investment and the Nordrhein-Westfalen local government with 10\% of the total investment, collects about 100 million Euros from governments (Xiaoling Ren, 2010, 17-19).

2.3 Use the dynamic management and connect the new ideas from strategic emerging industries and the new market smoothly

Along with the intellectual property products in emerging industries going into operation, the accelerated pace of new product updates, and customers' higher requirements for personalization, we must use appropriate ways and means to achieve R\&D control and connect the new ideas from strategic emerging industries and the new market smoothly in order to win in the market competition (Jinrong Peng \& Chunhong Li, 2011, 164). The IBM Corporation of the United States attaches great importance to the dynamic management of patent information and product R\&D. IBM adheres to the monthly release of technical bulletins to disclose some patent information and patent-pending technologies, collect related patent and technological information from the subordinate companies, as well as information of R\&D activities in professional sectors. According to the collected information, IBM will determine whether apply for patent or not, recommend the scope of the application, and provide professional consulting. Besides, IBM collects the dynamic information of patent and technology R\&D from other enterprises and promotes the new products of strategic emerging industries in the new market in purpose. Japanese enterprises also take the patent information, new product R\&D, and quality management as the primary tasks. For example, Mitsubishi separates the patent information center from the patent department and forms an independent firm. Mitsubishi especially emphasizes on the investigations of patent information before the patent application and the new products' market promotion. Starting from the technological innovation, to the final products, to the end consumer goods, it forms a complete industrial chain, industrial system, and relevant industrial R\&D control system, better adapting to the development of strategic emerging industries.

\section{The developed countries use the intellectual property to promote the development of strategic emerging industries: the enlightenment to China}

As the society enters the post-material era, economic development is experiencing a reform from the industrial economy to the creative economy. The famous economist P. Romer also pointed out that new ideas would produce endless new products, new markets, and new opportunities for wealth creation and new ideas would be the driving forces to the national economic growth. For a long time, a lot of resource-consuming industries cause serious environmental pollution and waste of resources in China. The market for technology policy also contributes to the shrinking of national industry market. Serious practical problems force China to adjust the economic and scientific \& technological development strategy. China should learn from the experiences of developed countries using the intellectual property to promote the development of strategic emerging industries, and achieve the sustainably development of strategic emerging industries in China by effectively using the intellectual property.

3.1 Establish the intellectual property-boosting strategy at the national level and provide guarantee for the development of strategic emerging industries

In recent years, multinational companies take advantages of Chinese enterprises' ignorance about the important role of intellectual property and the imperfect legal protection for the intellectual property, and launch a strategic invasion of intellectual property. Numerous Chinese enterprises fell into a patent pool or a brand trap and had to pay high compensation because of infringing on patents. In this context, China should plan and establish the intellectual property-boosting strategy at the national level, accelerate the fostering and the development of strategic emerging industries based on major technological breakthroughs and significant development needs, and promote the upgrading of industrial structure and the transformation of economic development pattern (Hongchang Liu, 2011). The implementation of this strategy needs the joint efforts of the Government, enterprises, scientific research institutions, industrial associations, and professional agencies. By this way, it can provide innovative powers and supports for strategic emerging industries, achieving the goal of promoting the development of strategic emerging industries by intellectual property. 
3.2 Build the intellectual property-boosting innovation system at the industrial level and provide impetus for the development of strategic emerging industries

Innovations are the sources of patent application, no innovations, no patent application. In China, the industry faces a core problem, i.e. the capability of independent innovation is weak and many enterprises have had no innovations or even patent products for years. According to the experiences of developed countries developing the strategic emerging industries, it is not feasible for the enterprise's scientific \& technological development department taking the responsibility of independent innovation. If the independent innovation is performed only by one enterprise individually, the enterprise may fail to find any clues to innovations or may be set up because of "isolated innovation". Therefore, we should build the intellectual property-boosting innovation system at the industrial level in order to provide impetus for the development of strategic emerging industries. Take full account of the conditions of China, highlight the independent innovation, make breakthroughs of core and key technologies in the most basic field with best conditions, seize the technological heights of industrial development, and achieve the strategic goal of building the emerging industries.

\subsection{Improve enterprises' capabilities of mastering and using intellectual property at the enterprise level}

Enterprises are the most important subjects of strategic emerging industries in China. They are the primary elements for the intellectual property-boosting strategy. As the basic level of strategic emerging industries, enterprises should combine their technological basis, industrial advantages, and allocation of domestic and foreign patents together, invest in $\mathrm{R} \& \mathrm{D}$, and arrange the patent layout, including technological innovations, as well as the use and protection of own intellectual property. However, for a long time China has had no innovation incentive mechanism, no intellectual property system, no R\&D institutions, and the R\&D investment has been far from sufficiency. This condition has been a serious impediment to the improvement of enterprises' capabilities of mastering and using intellectual property (Xinxin Wang, 2011). Therefore, we should improve the enterprises' capabilities of mastering and using the intellectual property and adopt a series of measures to make the technological innovation and the creation, implementation, management, and protection of intellectual property be the main theme and the conscious action for enterprise development. Enterprises should strengthen the effective incentives and restraints for scientific and technological developers, and reasonably carry out the activities of technological innovation and patent application. Meanwhile, enterprises can make best use of existing patents by further consumption, absorption, and recreation, and generate better patent technologies to be fully exploited in the competition. Besides, enterprises must attach great importance to patent application and planning, preventing legal disputes in the process of industrialization of technology and product.

\section{References}

General Office of the State Council of the People's Republic of China. (2010). Decision of the State Council on Accelerating the Fostering and Development of Strategic Emerging Industries. [EB/OL]. http://www. gov.cn/zwgk/2010-10/1 content_1724848.htm. 2010-10-18.

Li, Weina. (2009). Emerging industries: situations, problems, and countermeasures. Journal of the Graduates Sun YAT-SEN University (Social Sciences), 04.

Liu, Hongchang. (2011). Selective principles of Chinese and oriented research on cultivating policies. Science of Science and Management of $S \& T, 03$.

Peng, Jinrong \& Li, Chunhong. (2011). The developing trends and enlightenment of the strategic emerging industry overseas. Reformation \& Strategy, 2: 164.

Ren, Xiaoling. (2010). The Annual Report 2009 by European Patent Office: a sharp decrease of patent applications examined. China Invention \& Patent, 6: 17-19.

Wan, Gang. (2010). Grasp the opportunity of global industrial restructuring to nurture and develop strategic emerging industries. Science \& Technology Industry of China, 02.

Wang, Xinxin. (2011). Point analysis of technological breakthrough for strategic emerging industries. People's Daily, Dec. $22^{\text {nd }}$.

Zhao, Gang. (2010). Strategic emerging industries' international experiences and China's countermeasures. Scientific \& Technological Achievements, 01. 